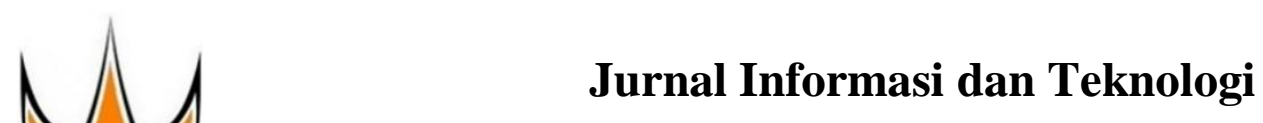

http://www.jidt.org

2022 Vol. $4 \quad$ No. $1 \quad$ Hal: 19-24

e-ISSN: 2714-9730

\title{
Kombinasi Tiga Algoritma Penjadwalan Sebagai Upaya Meningkatkan Pelayanan Pelanggan Pada Usaha Konveksi
}

\author{
Siti Mutrofin ${ }^{1 凶}$, M. Dimas Ghifari Muafah ${ }^{2}$, Mas'ud $^{3}$, Ahmad Farhan $^{4}$ \\ ${ }^{1}$ Teknik Informatika, Universitas 17 Agustus 1945 Surabaya, Surabaya, Indonesia \\ ${ }^{2,3,4}$ Sistem Informasi, Universitas Pesantren Tinggi Darul Ulum, Jombang, Indonesia \\ sitimutrofin@untag-sby.ac.id
}

\begin{abstract}
Konveksi Fariasi is a convection that focuses on the production of t-shirts in Jombang. The problem is experienced by Konveksi Fariasi is scheduling the production of customer order shirts based on the order of arrival time or First in First Serve (FCFS), where the first arrival will get the first service. FCFS is not profitable for customers who order a small number of t-shirts that are not included in the First or Initial queue, because they have to wait for previous queues which may have more orders in the front queue. FCFS does not benefit the ordering of $t$-shirts that are not in the first line even though the order is small. From these problems, the current production scheduling system needs to be optimized. In this study, the data used are ordering data for September 2017. The results of data analysis and business processes, this study propose a combination of three scheduling algorithms as a solution to improve customer service. The algorithm consists of Dynamic Priority, Shortest Job First (SJF) and First in First Serve (FCFS). Dynamic Priority is useful for customers who want to prioritize their orders, SJF is useful for small orders, FCFS is useful for sorting according to the earliest date of arrival. The trial results of the combination of the three algorithms show better results than just using FCFS. The average waiting time is 664 days for the combination of the three proposed algorithms, compared if only using the FCFS algorithm which is 747 days.
\end{abstract}

Keywords: Fisrt in First Out, First in First Serve, Dynamic Priority, Scheduling Algorithm, Shortest Job First.

\begin{abstract}
Abstrak
Konveksi Fariasi adalah konveksi yang berfokus pada produksi kaos yang berada di Jombang. Permasalahan yang dialami oleh Konveksi Fariasi dalam memproduksi kaos pesanan pelanggan biasanya dijadwalkan berdasarkan urutan waktu kedatangan atau First In First Serve (FCFS), di mana waktu kedatangan pertama akan dijadwalkan pada urutan pertama. FCFS tidak menguntungkan bagi pelanggan yang memesan kaos dengan jumlah sedikit tetapi terdaftar tidak diantrian pertama atau awal, karena harus menunggu antrian sebelumnya yang mungkin jumlah pesanan pada antrian di depannya lebih banyak. Dari permasalah tersebut, sistem penjadwalan produksi saat ini perlu dioptimalkan. Pada penelitian ini, data yang digunakan adalah data pemesanan bulan September 2017. Hasil analisis data dan proses bisnis, penelitian ini mengusulkan kombinasi tiga algoritma penjadwalan sebagai solusi meningkatkan layanan pelanggan. Algoritma tersebut terdiri dari Dynamic Priority, Shortest Job First (SJF) dan First In First Serve (FCFS). Dynamic Priority berguna untuk pelanggan yang ingin pengerjaan pemesanannya diprioritaskan, SJF berguna untuk jumlah pesanan sedikit, FCFS berguna untuk pengurutan sesuai tanggal kedatangan yang paling awal. Hasil uji coba kombinasi ketiga algoritma menunjukkan hasil yang lebih baik dari pada hanya menggunakan FCFS. Rata-rata waktu tunggu 664 hari untuk kombinasi ketiga algoritma yang diusulkan, dibandingkan jika hanya menggunakan algoritma FCFS yaitu 747 hari.
\end{abstract}

Kata kunci: Algoritma Penjadwalan, Dynamic Priority, First in First Out, First in First Serve, Shortest Job First.

(C) 2022 JIdT

\section{Pendahuluan}

Konveksi Fariasi adalah salah satu industri rumahan yang bergerak di bidang produksi kaos. Konveksi Fariasi bertempat di Desa Palrejo Kecamatan Sumobito Kabupaten Jombang Jawa Timur. Konveksi Fariasi memproduksi berbagai macam kaos berdasarkan pesanan dari konsumen, dengan permintaan yang bersifat Make to Order (MTO) atau kaos hanya akan diproduksi berdasarkan pesanan yang ada. Konveksi Fariasi menyadari pentingnya ketepatan waktu penyelesaian pesanan dalam mempertahankan konsumen dalam persaingan bisnis dengan rival yang bergerak di bidang usaha sejenis.
Saat ini, Konveksi Fariasi memiliki beberapa permasalahan, baik permasalahan dalam pencatatan pemesanan secara manual, maupun permasalahan dari sisi penjadwalan produksi berdasarkan pesanan pelanggan. Permasalahan yang timbul dari sistem pemesanan dilakukan secara manual dengan cara pelanggan datang secara langsung, menghubungi melalui SMS, atau telepon yang selanjutnya akan dicatat dalam buku besar. Kelemahan sistem ini adalah informasi rawan disalahpahami, karena pencatatan dilakukan dengan tulisan tangan, di mana tidak semua karyawan yang menangani pesanan memiliki kemampuan menulis dengan tulisan tangan secara rapi dan jelas ketika dibaca oleh orang lain. 
Banyak penelitian dengan permasalahan pemesanan manual di bidang usaha konveksi yang telah dilakukan. Sistem informasi pemesanan sablon kaos berbasis web untuk mengatasi permasalahan konveksi Legacyhero dengan tujuan untuk mempermudah pelanggan dalam membuat pesanan dan mengetahui status pemesanan secara online. Sistem menggunakan framework Laravel dan database MySQL [1]. Sistem informasi berbasis web menggunakan model Waterfall untuk pengembangan perangkat lunaknya [2], model Prototype [3], model Waterfall dan menerapkan framework CodeIgniter [4].

Sistem penjadwalan produksi kaos berdasarkan pesanan pelanggan belum optimal. Penjadwalan produksi kaos saat ini menerapkan First Come First Serve (FCFS) atau First in First Out (FIFO), di mana pesanan yang datang terlebih dulu akan dikerjakan terlebih dahulu. FCFS memiliki beberapa kelemahan, diantaranya adalah ketika ada pemesanan dalam jumlah sedikit akan membutuhkan waktu yang lama jika pesanannya bukan yang pertama; dan ketika ada pesanan yang ingin diprioritaskan pengerjaannya oleh pelanggan, tidak bisa ditangani jika pesanan tersebut masuk daftar antrian ke sekian bukan antrian pertama. Sedangkan beberapa pelanggan mengharapkan pesanan mereka diprioritaskan produksinya dan tidak mempermasalahkan adanya biaya tambahan. Namun, ada juga pelanggan yang tidak mempermasalahkan jika pesanan mereka akan diproduksi sesuai dengan antrian yang mereka dapatkan selama tidak ada biaya tambahan.

Beberapa penelitian terkait algoritma penjadwalan mengusulkan FCFS pada sistem pemesanan penggunaan lapangan futsal [5]; FCFS untuk penjadwalan terapi [6]. Namun FCFS memiliki kelemahan yaitu proses pengerjaannya memakan waktu lama, sehingga mengakibatkan peningkatan response time dan waiting time, proses selanjutnya [7] Penerapan Shortest Job First (SJF) guna mengatasi permasalahan pemesanan dengan jumlah sedikit, sehingga waktu pengerjaan lebih cepat, karena pemesanan dari pelanggan memiliki variasi jumlah pesanan [8]. SJF juga diterapkan pada jadwalan antrian pasien [9], monitoring job order [10], penjadwalan produksi patung [11]. Teknik Dynamic priority scheduling dalam prioritas selalu berubah dinamis sesuai kondisi, pesanan dialokasikan untuk proses yang memiliki prioritas lebih tinggi [12]. Kombinasi SJF dengan Dynamic priority untuk mengakomodir pesanan produk yang sama dengan antrian di depannya [13], [14]. Dynamic priority dapat mengokomodir kelemahan SJF dari sisi starvation [3].

Pada penelitian ini diusulkan menerapkan ketiga algoritma yang terdiri dari FCFS, SJF, dan Dynamic priority scheduling guna mengatasi permasalahan yang dihadapi oleh Konveksi Fariasi. Dynamic Priority berguna untuk pelanggan yang ingin pengerjaan pemesanannya diprioritaskan, SJF berguna untuk jumlah pesanan sedikit, FCFS berguna untuk pengurutan sesuai tanggal kedatangan yang paling awal.

\section{Metodologi Penelitian}

Metode penelitian ini mengacu pada pengembangan perangkat lunak berbasis model Waterfall. Ilustrasi model Waterfall disajikan pada Gambar 1 [15]. Penjelasan Gambar 1 pada penelitian ini disajikan pada Subbagian 2.1, 2.2, 2.3, dan 2.4.

\section{Sistem yang diusulkan

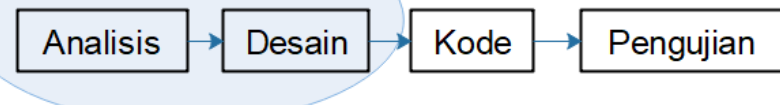 \\ Gambar 1. Model Waterfall [15]}

\subsection{Analisis}

Tahapan pertama yang harus dilakukan adalah pengumpulan data dan proses bisnis sistem yang berjalan. Pengumpulan data dan proses bisnis dilakukan menggunakan metode observasi dan pengumpulan dokumen yang dimiliki oleh Konveksi Farisi. Hasil pengumpulan data dilakukan analisis data, data apa saja yang digunakan dan proses bisnisnya seperti apa, baik proses bisnis sistem yang sedang berjalan maupun proses bisnis yang diusulkan. Data yang digunakan adalah data pada bulan September 2017. Tabel 1, Tabel 2 dan Gambar 2 adalah data yang didapatkan pada tahapan pengumpulan data.

Tabel 1. Harga kaos berdasarkan jenis kain

\begin{tabular}{lcccccc}
\hline \multicolumn{1}{c}{ JK } & $\begin{array}{c}\text { K. Pj } \\
(000)\end{array}$ & $\begin{array}{c}\text { K. Pd } \\
(000)\end{array}$ & $\begin{array}{c}\text { BM. Pj } \\
(000)\end{array}$ & $\begin{array}{c}\text { BM. Pd } \\
(000)\end{array}$ & $\begin{array}{c}\text { PL. Pj } \\
(000)\end{array}$ & $\begin{array}{c}\text { PL. Pd } \\
(000)\end{array}$ \\
\hline U-S & 48 & 43 & 43 & 38 & 43 & 38 \\
U-M & 48 & 43 & 43 & 38 & 43 & 38 \\
U-L & 48 & 43 & 43 & 38 & 43 & 38 \\
U-XL & 53 & 48 & 48 & 43 & 48 & 43 \\
U-2XL & 58 & 53 & 53 & 45 & 53 & 45 \\
U-3XL & 63 & 58 & 58 & 48 & 58 & 48 \\
U-JMB & 68 & 63 & 63 & 53 & 63 & 53 \\
\hline
\end{tabular}

Keterangan pada Tabel 1 terkait JK adalah Jenis kain; K. Pj adalah Kain katun lengan Panjang; K. Pd adalah Kain katun lengan pendek; BM. Pj adalah Kain BTM lengan Panjang; BM. Pd adalah Kain BTM lengan pendek; PL. Pj adalah Kain Polo lengan Panjang; dan PL. Pd adalah Kain Polo lengan pendek. Keterangan pada Tabel 2 terkait BT adalah Burst Time.

Gambar 3 menunjukkan proses bisnis sistem yang saat ini sedang berjalan yaitu:

a. Pelanggan melakukan pemesanan dengan mendatangi ke tempat produksi;

b. Pelanggan menentukan pesanan kaos dengan memilih model, jenis kain, dan warna kain;

c. Pelanggan menyepakati harga yang ditentukan oleh konveksi;

d. Pelanggan memberikan uang muka minimal $40 \%$ dari total harga; 
e. Pemilik konveksi mencatat pesanan, dari model kaos, warna, jenis kain, dan jumlah pesanan;

f. Pemilik konveksi menberikan intruksi pengerjaan kaos kepada karyawan;

g. Karyawan mengerjakan pesanan berdasarkan komando pemilik konveksi;

h. Produksi selesai dikerjakan;

i. Pemilik konveksi menghubungi pelanggan jika pesanan sudah selesai;

j. Pelanggan melakukan pelunasan dari sisa pembayaran;

k. Barang pesanan diambil secara langsung oleh pelanggan atau pemilik konveksi mengantar barang pesanan ke pelanggan.

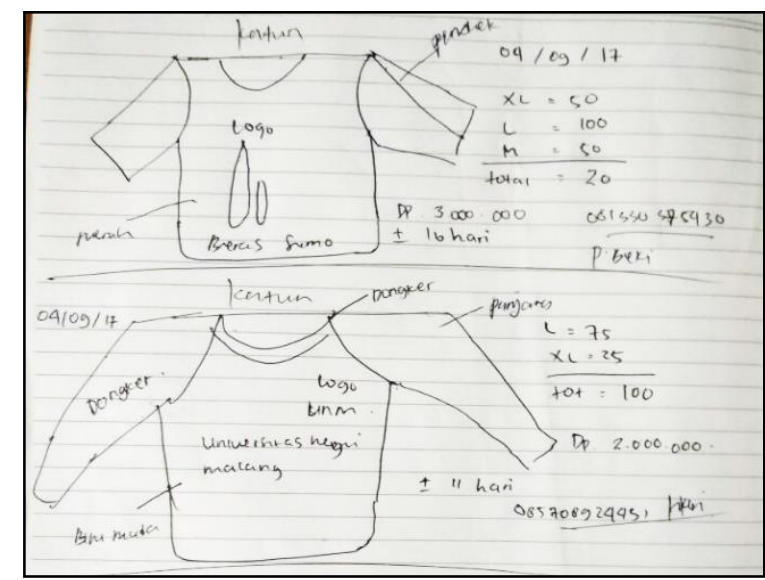

Gambar 2. Beberapa desain kaos pesanan pelanggan

Tabel 2. Contoh beberapa data pesanan bulan September 2017

\begin{tabular}{rlrlrr}
\hline No & Nama pesanan & Jumlah & Jenis & $\begin{array}{c}\text { Tanggal } \\
\text { pesan }\end{array}$ & $\begin{array}{c}\text { Lama } \\
\text { (BT) } \\
\text { (Hari) }\end{array}$ \\
\hline 1 & Beras Sumo & 200 & SJF & $4 / 09 / 2017$ & 16 \\
2 & Universitas Malang & 100 & SJF & $4 / 09 / 2017$ & 11 \\
3 & SMK Diponegoro & 230 & SJF & $10 / 09 / 2017$ & 18 \\
4 & KSDP Samba & 376 & SJF & $10 / 09 / 2017$ & 25 \\
5 & Kaos Panda & 30 & SJF & $10 / 09 / 2017$ & 8 \\
6 & Kaos CKM & 40 & Priority & $10 / 09 / 2017$ & 8 \\
7 & Kaos Gaslur & 60 & SJF & $10 / 09 / 2017$ & 9 \\
8 & Kaos Morotai & 10 & SJF & $11 / 09 / 2017$ & 7 \\
9 & Panitia Zakat & 35 & Priority & $11 / 09 / 2017$ & 8 \\
10 & DNR Drumb Band & 25 & SJF & $11 / 09 / 2017$ & 8 \\
\hline
\end{tabular}

Guna memperbaiki permasalahan yang ada pada sistem yang berjalan, maka diusulkan proses bisnis yang disajikan pada Gambar 4.

Berdasarkan pengumpulan data dan proses bisnis sistem yang diusulkan, maka kebutuhan fungsional yang ditawarkan adalah disajikan pada Tabel 3 . Sedangkan kebutuhan nonfungsional pada penelitian ini adalah kebutuhan perangkat lunak, perangkat keras, keamanan dalam hal ini diakomodir fitur Login, dan kinerja dalam hal ini akan diakomodir dalam perbandingan waktu tercepat antara penjadwalan sistem lama dengan sistem yang diusulkan [15].

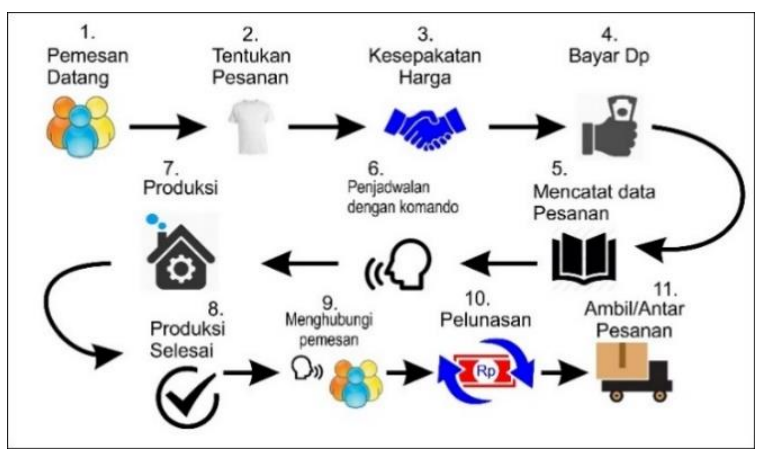

Gambar 3. Sistem yang sedang berjalan

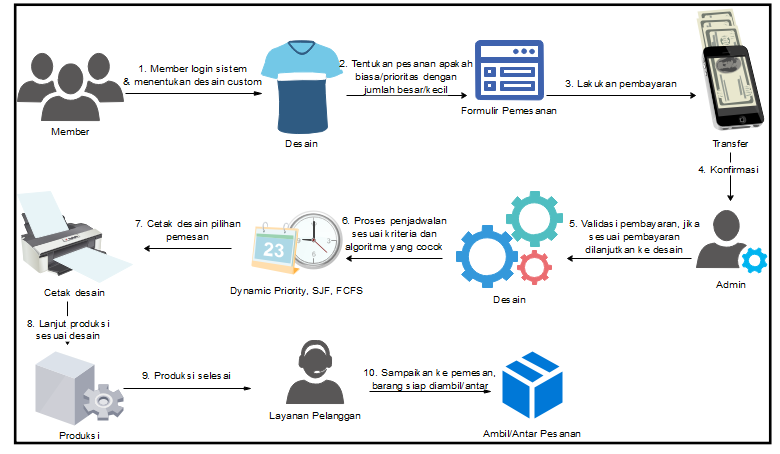

Gambar 4. Sistem yang diusulkan

Tabel 3. Kebutuhan Fungsional

\begin{tabular}{ll}
\hline User & \multicolumn{2}{c}{ Hak Akses } \\
\hline Admin & 1. Melakukan Login \\
& 2. Mengelola atau melakukan operasi CRUD \\
& \multicolumn{2}{c}{ (Create, Read, Update, Delete) data artikel, } \\
& Bank, Admin, Member, Kategori, Produk \\
& 3. Mengelola data order \\
& 4. Konfirmasi bayar \\
& 5. Mengelola data penjadwalan \\
& 6. Cetak laporan order \\
& 7. Cetak detail produk order \\
8. Logout \\
Member & 1. Melakukan pemesanan \\
& 2. Konfirmasi bayar \\
3. Edit akun \\
4. Melakukan testimonial produk \& hubungi kami
\end{tabular}




\subsection{Desain}

Pada tahapan ini dilakukan desain, baik desain database maupun pemodelan pengembangan perangkat lunak yaitu Unified Modeling Language (UML) dan user interface.

\subsection{Kode}

Pada tahapan kode, beberapa software digunakan, diantaranya adalah MySQL untuk database, PHP native dan JavaScript untuk Bahasa pemrograman, Sublime Text untuk editor, Mozilla untuk browser, dll. Algoritma penjadwalan yang akan digunakan adalah tiga algoritma, diantaranya adalah SJF (Tabel 4), SJF dan Priority (Tabel 5), Dynamic priority (Gambar 5), dan FCFS (Tabel 6 dan Gambar 6).

Tabel 4. Urutan penjadwalan berdasar SJF

\begin{tabular}{clcr}
\hline No & Proses & Arival Time (AT) & Lama (BT) (hari) \\
\hline 1 & P2 & $4 / 09 / 2017$ & 11 \\
2 & P1 & $4 / 09 / 2017$ & 16 \\
3 & P6 & $10 / 09 / 2017$ & 8 \\
4 & P5 & $10 / 09 / 2017$ & 8 \\
5 & P7 & $10 / 09 / 2017$ & 9 \\
6 & P3 & $10 / 09 / 2017$ & 18 \\
7 & P4 & $10 / 09 / 2017$ & 25 \\
8 & P9 & $11 / 09 / 2017$ & 8 \\
9 & P8 & $11 / 09 / 2017$ & 7 \\
10 & P10 & $11 / 09 / 2017$ & 8 \\
\hline
\end{tabular}

Tabel 5. Urutan penjadwalan berdasar SJF dan Priority

\begin{tabular}{rlrlrc}
\hline No & Proses & $\begin{array}{c}\text { Arival Time } \\
\text { (AT) }\end{array}$ & Status & $\begin{array}{c}\text { Nilai } \\
\text { Priority }\end{array}$ & $\begin{array}{c}\text { Lama } \\
\text { (BT) } \\
\text { (hari) }\end{array}$ \\
\hline 1 & P2 & $4 / 09 / 2017$ & SJF & 1 & 11 \\
2 & P1 & $4 / 09 / 2017$ & SJF & 2 & 16 \\
3 & P6 & $10 / 09 / 2017$ & Priority & 3 & 8 \\
4 & P5 & $10 / 09 / 2017$ & SJF & 4 & 8 \\
5 & P7 & $10 / 09 / 2017$ & SJF & 5 & 9 \\
6 & P3 & $10 / 09 / 2017$ & SJF & 6 & 18 \\
7 & P4 & $10 / 09 / 2017$ & SJF & 7 & 25 \\
8 & P9 & $11 / 09 / 2017$ & Priority & 8 & 8 \\
9 & P8 & $11 / 09 / 2017$ & SJF & 9 & 7 \\
10 & P10 & $11 / 09 / 2017$ & SJF & 10 & 8 \\
\hline
\end{tabular}

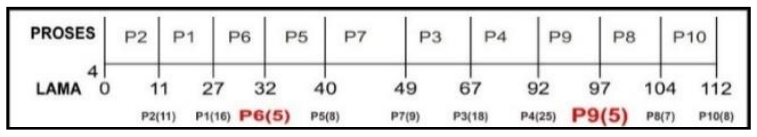

Gambar 5. Urutan proses penjadwalan Dynamic Priority

Tabel 6. Urutan tanggal kedatangan dengan FCFS

\begin{tabular}{lcccc}
\hline No & Proses & $\begin{array}{c}\text { Arival Time } \\
\text { (AT) }\end{array}$ & Satatus & $\begin{array}{c}\text { Lama(BT) } \\
\text { (hari) }\end{array}$ \\
\hline 1 & P1 & $4 / 09 / 2017$ & SJF & 16 \\
2 & P2 & $4 / 09 / 2017$ & SJF & 11 \\
3 & P3 & $10 / 09 / 2017$ & SJF & 18 \\
4 & P4 & $10 / 09 / 2017$ & SJF & 25 \\
5 & P5 & $10 / 09 / 2017$ & SJF & 8 \\
6 & P6 & $10 / 09 / 2017$ & Priority & 8 \\
7 & P7 & $10 / 09 / 2017$ & SJF & 9 \\
8 & P8 & $11 / 09 / 2017$ & SJF & 7 \\
9 & P9 & $11 / 09 / 2017$ & Priority & 8 \\
10 & P10 & $11 / 09 / 2017$ & SJF & 8 \\
\hline
\end{tabular}

Jurnal Informasi dan Teknologi Vol . 4 No. 1 (2022) 19-24

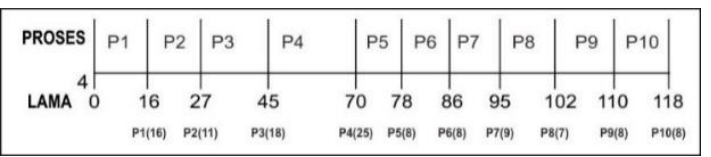

Gambar 6. Urutan proses penjadwalan FCFS

\subsection{Pengujian}

Tahap ini dilakukan pengujian sistem yang diusulkan. Pengujian pertama didasarkan pada pengujian blackbox dan pengujian kedua adalah perbandingan kinerja algoritma yang diusulkan dengan sistem yang sedang berjalan untuk membutuhkan apakah benar bahwa usulan berhasil memperbaiki kinerja penjadwalan sistem lama, sehingga dapat meningkatkan layanan kepada pelanggan. Banyak skenario uji coba dalam pengujian use case di fitur yang sudah dibuat pada aplikasi ini. Namun, untuk mempersingkat dan menjawab tujuan apakah tercapai atau tidak maka pengujian yang disajikan pada artikel ini hanya difokuskan pada use case pemesanan kaos secara online, konfirmasi pembayaran, dan penjadwalan.

Pengujian use case custom order kaos merupakan pengujian yang dilakukan oleh member. Tujuan dari pengujian untuk menguji fungsi dari halaman custom order, member mengisi text maupun gambar dengan kriteria data sesuai yang disediakan oleh sistem atau aplikasi. Pengujian use case pilih status pemesanan merupakan pengujian yang dilakukan oleh member. Tujuan dari pengujian untuk menguji fungsi dari halaman pilih status pemesanan, member mengisi pilihan status pemesanan, jika status pesanan prioritas maka akan dikenakan biaya tambahan jika nonprioritas pesanan dijadwalkan berdasarkan urutan jumlah terkecil dari pemesanan. Pengujian use case pembayaran pada merupakan pengujian yang dilakukan pada level member. Tujuan dari pengujian untuk menguji fungsi dari halaman pembayaran, member mengisi data pembayaran dengan kriteria data sesuai yang disediakan oleh sistem atau aplikasi.

\section{Hasil dan Pembahasan}

Perbandingan pada perhitungan manual mengurutkan pesanan berdasarkan waktu dan tanggal kedatangan, di mana waktu kedatangan yang pertama akan mendapat antrian dikerjakan/diproses lebih dulu, penjadwalan ini kurang optimal karena pemesanan dengan jumlah sedikit akan mendapat urutan proses pengerjaan yang panjang dibanding pemesanan jumlah banyak dengan waktu kedatangannya lebih dulu. Hasil penjadwalan manual yang ada pada Konveksi Fariasi berdasarkan tanggal kedatangan, ditampilkan pada Tabel 7. 
Pada Tabel 7, penjadwalan dilakukan berdasarkan waktu kedatangan, waktu kedatangan pertama akan dikerjakan pada urutan pertama, waktu kedatangan kedua akan dikerjakan pada urutan kedua, begitu seterusnya hingga semua pesanan pada kedatangan terakhir telah selesai dikerjakan. Penjadwalan seperti itu belum optimal, dilihat pada pemesanan ke-lima dengan lama waktu produksi 8 hari, harus menunggu antrian waktu produksi pada urutan ke-emapat yaitu 25 hari dkarenakan waktu kedatanganya sesudah pemesanan pada urutan ke-empat.

Penjadwalan dengan metode yang diusulkan pada penelitian ini, hasil uji coba lebih optimal dari penjadwalan manual yang menggunakan FCFS berdasarkan waktu kedatangan. Penjadwalan ini mengatasi masalah pelanggan yang memesan kaos pada Konveksi Fariasi dengan pencatatan data tersistem komputerisasi berbasis web. Konveksi dapat melakukan pencarian data pemesanan lebih mudah, dalam menjadwalkan produksi dilakukan dengan mengurutkan pemesanan dengan waktu proses produksi yang lebih kecil, sehigga pemesanan dengan jumlah sedikit tidak harus menunggu lama dengan pemesanan dengan jumlah yang bayak, hal tersebut dapat diselesaikan dengan adanya metode SJF.

Metode yang diusulkan pada penelitian ini juga mengatasi permasalahan dengan permintaan dari pemesanan yang ingin mendapatkan urutan produksi lebih awal yang jumlah pemesanan bersifat dinamis, sesuai dengan konsekuensi bahwa penjadwalan dengan prioritas akan dibebankan biaya tambahan per kaos, hal dapat diselesaikan dengan metode Dynamic Priority.

Tabel 7. Hasil penjadwalan manual berdasarkan waktu kedatangan

\begin{tabular}{rlrrc}
\hline No & Nama pesanan & $\begin{array}{c}\text { Jumlah } \\
\text { (buah) }\end{array}$ & Tgl pesan & $\begin{array}{c}\text { Lama } \\
\text { (BT) } \\
\text { (hari) }\end{array}$ \\
\hline 1 & Beras Sumo & 200 & $4 / 09 / 2017$ & 16 \\
2 & Universitas Mlg & 100 & $4 / 09 / 2017$ & 11 \\
3 & Smk Diponegoro & 230 & $10 / 09 / 2017$ & 18 \\
4 & KSDP Samba & 376 & $10 / 09 / 2017$ & 25 \\
5 & Kaos Panda & 30 & $10 / 09 / 2017$ & 8 \\
6 & Kaos CKM & 40 & $10 / 09 / 2017$ & 8 \\
7 & Kaos Gaslur & 60 & $10 / 09 / 2017$ & 9 \\
8 & Kaos Morotai & 10 & $11 / 09 / 2017$ & 7 \\
9 & Panitia Zakat & 35 & $11 / 09 / 2017$ & 8 \\
10 & DNR Drumb Band & 25 & $11 / 09 / 2017$ & 8 \\
\hline
\end{tabular}

Keseluruhan penjadwalan dilakukan dengan Dynamic Priority maupun SJF, diurutkan berdasarkan tanggal kedatangan dengan metode FCFS di mana waktu tanggal kedatangan sesuai dengan urutan yang berlaku yaitu tanggal kedatangan pertama akan dilakukan penjadwalan dengan urutan pertama, tetapi dalam setiap tanggal didalamnya diurutkan dengan metode SJF dan Dynamic Priority untuk menyelesaikan permasalahan yang ada pada konveksi Fariasi.

Pengujian selanjutnya adalah untuk membandingkan perhitungan dengan cara manual FCFS dengan perhitungan menggunakan sistem yang diusulkan dengan kombinasi tiga algoritma penjadwalan FCFS, SJF, dan Dynamic Priority. Hasil perbandingan kedua sistem didasarkan Burst Time (BT) atau lama proses pengerjaan dengan waktu tunggu atau Waiting Time (WT) ditampilkan pada Tabel 8.

Tabel 8 didapatkan hasil perhitungan manual dan perhitungan sistem yang diusulkan dengan menggunakan kombinasi ketiga algoritma penjadwalan. Perhitungan dengan sistem yang sedang berjalan membutuhkan rata-rata waktu tunggu 747 hari, sedangkan perhitungan menggunakan sistem yang diusulkan membutuhkan rata-rata waktu tunggu 664 hari, antara perhitungan manual dan sistem yang diusulkan didapat selisih waktu tunggu rata-rata 83 hari. Sehingga didapatkan hasil perhitungan menggunakan sistem yang diusulkan membutuhkan rata-rata waktu tunggu yang lebih pendek sesuai dengan tujuan penelitian ini.

Tabel 8. Perbandingan perhitungan manual dan hasil sistem yang diusulkan menggunakan kombinasi ketiga algoritma penjadwalan

\begin{tabular}{rcrrlrrr}
\hline No & $\begin{array}{c}\text { Tanggal } \\
\text { pesan }\end{array}$ & FCFS & $\begin{array}{c}\text { BT } \\
\text { (hari) }\end{array}$ & WT & $\begin{array}{c}\text { Algoritma } \\
\text { yang } \\
\text { diusulkan }\end{array}$ & $\begin{array}{c}\text { BT } \\
\text { (hari) }\end{array}$ & WT \\
\hline 1 & $4 / 09 / 2017$ & & 16 & 16 & P2 & 11 & 11 \\
2 & $4 / 09 / 2017$ & & 11 & 27 & P1 & 16 & 27 \\
3 & $10 / 09 / 2017$ & & 18 & 45 & P6 & 8 & 35 \\
4 & $10 / 09 / 2017$ & & 25 & 70 & P5 & 8 & 43 \\
5 & $10 / 09 / 2017$ & 8 & 78 & P7 & 9 & 52 \\
6 & $10 / 09 / 2017$ & 8 & 86 & P3 & 18 & 70 \\
7 & $10 / 09 / 2017$ & 9 & 95 & P4 & 25 & 95 \\
8 & $11 / 09 / 2017$ & 7 & 102 & P9 & 8 & 103 \\
9 & $11 / 09 / 2017$ & 8 & 110 & P8 & 7 & 110 \\
10 & $11 / 09 / 2017$ & 8 & 118 & P10 & 8 & 118 \\
\hline & Total & 118 & 747 & & 118 & 664 \\
\hline
\end{tabular}

\section{Kesimpulan}

Berdasarkan hasil uji coba dan pembahasan yang telah dilakukan, dapat diambil kesimpulan bahwa aplikasi pemesanan dan penjadwalan produksi kaos dengan metode menggabungkan ketiga algoritma penjadwalan yang terdiri dari Dinamic Priority, SJF dan FCFS berbasis web dapat mengatasi permasalahan pemesanan dengan prioritas dan sesuai dengan karakteristik data yang didapatkan dari hasil pengumpulan data pada konveksi Fariasi Jombang. Sistem pemesanan yang diusulkan dapat membantu konsumen yang tidak memiliki banyak waktu untuk datang ke tempat usaha untuk memesan kaos secara online. Sistem pemesanan pemesanan dan penjadwalan produksi kaos yang diusulkan dapat mengatasi permasalahan dalam pencatatan order dan penjadwalan secara lebih optimal.

Pekerjaan di masa mendatang dapat menambahkan desain kaos lebih detail, seperti pada bagian belakang kaos, lengan samping kanan dan kiri. Pengembangan sistem dengan teknologi terbaru yang mendukung fitur-fitur untuk 1) Desain yang lebih baik seperti penggunaan berbasis mobile; 2) Fitur pengiriman barang yang terintegrasi dengan pihak penyedia jasa logistik pengiriman seperti kantor Pos J\&T dan JNE; 3) Fitur $e$-money seperti $e$-wallet; 4) Pelacakan proses barang sudah diproses atau belum; 5) tracking 
pesanan; 6) Rekomendasi desain populer yang ada pada template dan jenis kain terpopuler; dan 7) Tanggal pemesanan otomatis sesuai dengan hari pemesanan.

\section{Daftar Rujukan}

[1]. Suharno, J. J. (2018). Akhir Sistem Pemesanan Sablon Kaos Legacyhero Berbasis Web. Yogyakarta: Universitas Gadjah Mada.

[2]. Sabaruddin, R., Juniarti, M., Ardiyansyah, \& Nugraha, W. (2020). Pengembangan Sistem Informasi Perusahaan Konveksi dan Sablon Berbasis Website Menggunakan Metode Waterfall. JUSTIAN, Jurnal Sistem Informasi Akuntansi, 1(1), 21-30. doi: 10.31294/justian.v1i1.281

[3]. Ahmad, S., Ahmad, I., \& Mirdha, S. (2017). A Novel Dynamic Priority Based Job Scheduling Approach for Cloud Environment. International Research Journal of Engineering and Technology (IRJET), 4(6), 518-522.

[4]. Ramadhani, M., Rosely, E., \& Wijayanto, P. W. (2019) Aplikasi Pemesanan Produk Konveksi Berbasis Web pada Greens Production Bandung. e-Proceedings of Applied Science, (pp. 1994-2008).

[5]. Widodo, T. (2018). Sistem Pemesanan Penggunaan Lapangan Futsal dengan Algoritma First Come First Served Berbasis Website (Studi Kasus Bardosono Happy Futsal Yogyakarta). Yogyakarta: Universitas Teknologi Yogyakarta.

[6]. Hadi, R., \& Nugrahaeni, Y. (2016). Aplikasi Penjadwalan Terapi dengan Metode FCFS pada Sixo Reflexology. JAIS (Journal of Applied Intelligent System), 1(2), 134-143. doi: 10.33633/jais.v1i2.1190

[7]. Prasetyo, T. W., Wiharto, \& Doewes, A. (2015). Pemodelan Penjadwalan Multilevel Feedback Queue Menggunakan Dynamic Time Quantum Pada Kasus Pemesanan Makanan di Restoran. Itsmart : Jurnal Ilmiah Teknologi dan Informasi, 4(2), 92-100. doi: 10.20961/itsmart.v4i2.1772
[8]. Julianto, T. (2014). Penjadwalan Produksi Percetakan dengan Metode Shortest Job First untuk Optimalisasi Waktu Proses Produksi Studi Kasus CV. Syauqi Press. Semarang: Universitas Dian Nuswantoro.

[9]. Winardi, F., \& Kurniawan, R. (2017). Rancang Bangun Mobile Reservation Hemodialisis dengan Metode Shortest Job First (SJF) pada Rumah Sakit Graha Husada Bandar Lampung. Prosiding Seminar Nasional Darmajaya.

[10]. Octaviano, T. M., Ginting, N. B., \& Kusumah, F. S. (2018). Rancang Bangun Monitoring Job Order dengan Metode Shortest Job First pada CV. Mug Bogor. Prosiding Seminar Nasional Teknik Informatika (SEMNATI), (p. 714). Universitas Ibn Khaldun.

[11]. Ikhwan, M. (2015). Rancang Bangun Sistem Informasi Penjadwalan Produksi Kerajinan Patung Menggunakan Metode Shortest Job First di UD. Budha Special. Jombang: Universitas Pesantren Tinggi Darul Ulum.

[12]. Alie, D. F. (2013). Rancang Bangun Sistem Informasi Penjadwalan Produksi Sandal Dengan Metode Shortest Job First Pada CV. Djibril Jaya. Surabaya: Sekolah Tinggi Manajemen Informatika dan Teknik Komputer.

[13]. Nugrahanto, Y. (2011). Rancang Bangun Sistem Penjadwalan Produksi dengan Kombinasi Algoritma Shortest Job First dan Dynamic Priority Scheduling. Surabaya: Sekolah Tinggi Manajemen Informatika dan Teknik Komputer.

[14]. Nugraha, R. (2018). Sistem Informasi Pemesanan dan Produksi pada Revolver Konveksi Berbasis Web. Bandung: Universitas Komputer Indonesia.

[15]. Sukamto, A., \& Shalahuddin, M. (2011). Modul Pembelajaran Rekayasa Perangkat Lunak (Terstruktur dan Berorientasi Objek). Bandung: Modula. 